\title{
Natural radioactivity measurement of gold mine tailings in Vatukoula, Fiji Islands
}

\author{
Adimaitoga T. William Rabuku ${ }^{1}$ and Abdul Q. Malik ${ }^{2,}$ \\ ${ }^{1}$ Department Meteorology \& Environmental Science, College of Applied Sciences, Fiji National University, PO Box 5529, \\ Lautoka, Fiji \\ 2 Department of Physics, School of Pure Sciences, College of Engineering, Science and Technology, Fiji National University, \\ PO Box 5529, Lautoka, Fiji
}

Received: 22 May 2020 / Accepted: 13 June 2020

\begin{abstract}
Gold mining is one of the primary industry in Fiji, and it could expose the naturally occurring radioactive materials (NORMs) that may produce health risk to the people working in mining. The present study focuses on the assessment of soil samples in the vicinity of gold mining to assess the concentration of these nuclides. The average activity concentrations of Uranium $\left({ }^{238} \mathrm{U}\right)$, Thorium $\left({ }^{232} \mathrm{Th}\right)$ and Potassium $\left({ }^{40} \mathrm{~K}\right)$ in the soil samples from the gold mining area in Vatukoula, Fiji were computed using NaI(Tl) detector. The activity concentrations varied from $30.7 \mathrm{~Bq} \mathrm{~kg}^{-1}$ and $175.73 \mathrm{~Bq} \mathrm{~kg}^{-1}$ for ${ }^{238} \mathrm{U}$ and ${ }^{40} \mathrm{~K}$ with the absence of ${ }^{232} \mathrm{Th}$ in the decommissioned site. $19.49 \mathrm{~Bq} \mathrm{~kg}^{-1}, 123.06 \mathrm{~Bq} \mathrm{~kg}^{-1}$ and $86.86 \mathrm{~Bq} \mathrm{~kg}^{-1}$ was determined for ${ }^{238} \mathrm{U}^{232}{ }^{23 h}$ and ${ }^{40} \mathrm{~K}$ of the commissioned sites respectively which is less than the world averages according to the United Nations Scientific Committee on the Effects of Atomic Radiation report [1], except for ${ }^{232} \mathrm{Th}$ which is expected to be higher due to the mineral composition of monazite derivatives. Our preliminary results on the activity of these radioactive nuclides demonstrate that the mining activities at Vatukoula poses no significant radionuclide hazard to the miners and the general public.
\end{abstract}

\section{Introduction}

Naturally occurring radioactive materials (NORMs) is an integral component of our environment since the formation of our planet, Earth. The source of these could be of cosmic, terrestrial, or internal. The concentration of these materials in the environment at amounts that are not potentially risky to human health. [2] stated that NORMs account for up to $85 \%$ of the annual dose exposure received by the world population. These researchers reported that in certain cases, anthropogenic activities, such as mining, have produced wastes that contain radiation above background levels in the environment, a situation that has been a major concern for radiation protection. Mining has the potential to pollute soils over a large area through radiation exposure and other environmental contaminants [2,3]. It has been noted that the contamination of soil due to mining could affect humans in two ways: external or internal ingestion and inhalation $[1,4]$.

\footnotetext{
* e-mail: Abdul.Malik@fnu.ac.fj
}

It has been reported that gold mine tailings dumps are large sources of radium $\left({ }^{226} \mathrm{Ra}\right)$ and leading this industry as one of the major causes of elevation of NORM's concentrations on the Earth's surface. The general public is exposed to ionizing radiation from radionuclides that are present in different types of natural sources [1]. Considering the health risks associated with exposure to natural radionuclides, international, regional and local organizations-such as the International Commission on Radiological Protection (ICRP) and the United States Environmental Protection Agency (USEPA) have set standards and legislation to minimize such exposure [5]. It is well documented that soils and rocks of granite contain significant amounts of three terrestrial radionuclides: ${ }^{232} \mathrm{Th},{ }^{235} \mathrm{U},{ }^{238} \mathrm{U}$ (decay chains), and ${ }^{40} \mathrm{~K}$ [3,6-15]. When the mined material is brought to the surface it could increase the background radiation levels leading to expose with the higher dose of gamma radiation to miners and people living around mining tailing areas [1].

The aim of this study was to measure the amount of radioactive materials in soils from mine tailings around a gold mine in Vatukoula, Fiji. 


\section{Description of study area}

\subsection{Location of the study area}

Fiji located in the South Pacific Ocean consisting of 300 islands (about 100 of which are inhabited) and 540 islets located at $18^{\circ}$ South and $179^{\circ}$ East contains valuable metal deposits. Vatukoula is a gold mining settlement situated $9 \mathrm{~km}$ from Tavua town in West Fiji.

Vatukoula is located inside the Nasivi Catchment, and the Nasivi River drains it [16]. Mining, sugar cane and pine farming on upper ridges, and livestock grazing are the major user of the catchment area. The Nasivi River runs through the mangroves of the Tavua Delta and merges to the Pacific Ocean through two primary channels, the Nasivi and the Nasiriti [16]. The river water in this area is used by the livestock and not for irrigation. Both the Nasivi River and Tavua Delta support marine wildlife that is one of the means of earning of the people living in this area.

\subsection{Geology of the study area}

The Pacific Ring of Fire lies between the Indo Australia and the pacific Plates that is known for major mineral deposits and porphyry deposits. Papua New Guinea, the Solomon Islands, and New Zealand's North Island are regions of such natural resources. Gold deposits at Vatukoula could be formed during a period of volcanic activity a few million years ago. The volcanic activity on the ancient rocks transformed these as potassium that evolved from absarokite parent magma to shoshonite, banakite and monzonite derivatives [17]. The present gold activity at Vatukoula is located within a two square kilometer cracked block limited to a depth of within 600 meters. It has been noted that gold primarily is found in three kinds of basic settings that are steeply dipping northwest representing striking shears; flat dipping fractures, and shatter blocks between shears [17]. The gold deposits at Vatukoula is known as a Low-Sulfidation epithermal. There are two major types of epithermal gold deposits: Low-Sulfidation (LS) and High-Sulfidation (HS). Each of these is formed from waters of varying chemical composition, and in an appropriate volcanic environment. The presence of LS epithermal gold deposits is commonly related with the presence of the following metals: Silver $(\mathrm{Ag})$, Lead $(\mathrm{Pb})$, Copper $(\mathrm{Cu})$, Zinc $(\mathrm{Zn})$, Arsenic (As), Mercury ( $\mathrm{Hg})$, Selenium (Se), Cadmium (Cd), and sometimes Antimony (Sb) [18].

\subsection{Sample collection and preparation}

Two mine tailing sites were considered in this study that belongs to the Vatukoula Gold Mine Fiji Limited (VGML). These were the decommissioned and commissioned site which is currently in use. Five soil tailing samples were collected from the sites. Samples were collected randomly from the decommissioned site and mixed as one sample. The commissioned sites were collected from 200 meters away, dried sediment, decant and the main discharge pipe (source) to ensure a good statistical representation of the sampling sites [19]. The location of samples is identified with the use of Global Positioning System (GPS).

The samples were air-dried for a period of three days and thereafter oven-dried overnight at a temperature of $105^{\circ} \mathrm{C}$. This was done to ensure that moisture was completely removed from the samples in order to avoid clamping of the sample particles during crushing. The samples were then crushed using a mortar and pestle into powder form in order to increase the surface area. A sieve of mesh size $2 \mathrm{~mm}$ recommended in IAEA (2003) was used to obtain uniform particle sizes. The sieved samples were weighed using a digital balance to determine their dry masses. The known samples were then sealed in standard $1000 \mathrm{ml}$ plastic containers and kept for a period of 4 weeks to attain secular equilibrium with some progenies of ${ }^{238} \mathrm{U}$ and ${ }^{232} \mathrm{Th}$ (IAEA).

\subsection{Lead shielding and detector calibrations}

The Sodium Iodide Thallium Gamma-Ray NAI(Tl) Detector was used to detect the gamma-rays and their energies. Gamma-Ray Spectrometry has an Integral Assembly (consisting of a $38 \mathrm{~mm} \times 38 \mathrm{~mm} \quad \mathrm{NaI}$ (TI) Scintillator, Photomultiplier Tube (PMT) Base with Stand, and NIM Bin Scintillation Amplifier with MAESTRO Software. The assembly consisting of the detector and the sample holder was surrounded with the lead bricks with a dimension of $20 \mathrm{~cm} \times 10 \mathrm{~cm} \times 3 \mathrm{~cm}$ each to provide shielding to isolate it from the background radiation gamma-radiation. The energy and efficiency calibrations of the detector were performed with a standard $\gamma$-ray of $0.25 \mu \mathrm{Ci}$ active ${ }^{137} \mathrm{Cs}$ source and briefly discussed by Malik and Ashmit [20].

\subsection{Radionuclide identification}

Each sample was put on the gamma-ray detector and the detector was surrounded with a lead shield with a movable top, to minimize the background radiation. In addition, the setup was coupled with a computer-based multichannel analyzer (MCA), which will be used for data acquisition and analysis of gamma spectra. Counting was done for a minimum time of 36000 seconds to obtain a clear spectrum. Using MAESTRO software, the energy and intensity of the gamma rays were obtained for each sample spectra. Every observed energy peak on the gamma spectrum was compared with the standard energy peaks as per the IAEA for the various radionuclides in nature. The radionuclides resulting into the observed energy peaks on the spectrum of each sample were identified.

\subsection{Measurement of activity concentration}

The activity concentrations of ${ }^{238} \mathrm{U},{ }^{232} \mathrm{Th}$ and ${ }^{40} \mathrm{~K}$ were calculated based on the weighted values of their respective daughter products in secular equilibrium. In this analysis, ${ }^{238} \mathrm{U}$ was considered as it accounted for its daughter products, such as ${ }^{226} \mathrm{Ra}$. The activity levels for each radionuclide identified in the samples were determined by 
subtracting the background radiation counts from the total photo-peak areas within the region of interest. The activity of ${ }^{238} \mathrm{U}$ was determined from its decay products ${ }^{214} \mathrm{Bi}$ $(1401.56 \mathrm{KeV})$ and ${ }^{214} \mathrm{Bi}(1377.66 \mathrm{KeV})$ while ${ }^{214} \mathrm{Bi}(609$ $\mathrm{keV}$ ) in secular equilibrium with radium ${ }^{226} \mathrm{Ra}$. The activity of ${ }^{232} \mathrm{Th}$ was determined from its decay products ${ }^{212} \mathrm{~Pb}(1377.66 \mathrm{keV})$, while the activity concentration of ${ }^{40} \mathrm{~K}$ was determined from its own gamma spectrum at $1460.8 \mathrm{keV}$ (IAEA 2007). Details on the methodology to measure the activity concentration can be found in a number of references [21] The activity (A) of radionuclide of ${ }^{238} \mathrm{U}^{232} \mathrm{Th}$ and ${ }^{40} \mathrm{~K}$ in each sample in $\mathrm{Bq} \mathrm{kg}^{-1}$ (dry mass) was calculated using the following equation:

$$
\begin{aligned}
& \text { Activity }\left(\mathrm{Bq} \mathrm{kg}^{-1}\right): A\left({ }_{\mathrm{Z}}^{\mathrm{A}} X\right)=\left(\frac{\Delta \text { Counts }}{t_{L}}\right) \cdot \frac{1}{G \varepsilon_{p} f} \\
&: \text { Activity per unit mass }
\end{aligned}
$$

where $t_{L}$ is the live time in seconds, $\varepsilon_{p}$ is the intrinsic peak efficiency for the gamma ray energy and detector size used, $G$ is the geometry factor $=\frac{\text { area of detector }}{4 \pi s^{2}}=\frac{\pi r^{2}}{4 \pi s^{2}}, f$ is the fraction of the total disintegrations, $s$ is the source to detector distance in meters and

$$
\begin{aligned}
& \Delta \text { Counts }_{(\text {Conventional Method })} \\
& =\left[\begin{array}{l}
\text { Total counts in the photopear } \\
\text { encompassed region with } \\
\text { sample }
\end{array}\right] \\
& -\left[\begin{array}{l}
\text { Total counts in the photopear } \\
\text { encompassed region without } \\
\text { sample }
\end{array}\right] .
\end{aligned}
$$

\section{Results and discussion}

Activity concentration of ${ }^{238} \mathrm{U},{ }^{232} \mathrm{Th}$ and ${ }^{40} \mathrm{~K}$ in the soil samples of Gold Mine in Vatukoula, Fiji, was calculated with the use of lead bricks surrounded and well-calibrated $38 \mathrm{~mm} \times 38 \mathrm{~mm} \mathrm{NaI}(\mathrm{Tl})$ detector.

The soils, standards and background were counted under identical conditions of sample-detector geometry and counting time (36000 seconds). The background counts were obtained by measuring a complete gamma profile of an empty container after three trails. The background counts were subtracted from the total gammaray spectra of elemental composition in soil samples to get the net counts. Four samples of equal mass tabulated in Table 1 were collected at random from the decommissioned site to form a homogenous sample. Dried tailings were very dry soils from barren wasteland in the commissioned site and are shown in Figure 2. Samples were also taken from $200 \mathrm{~m}$ away within the tail dumps; decant was taken from settled sediments and the source from the main discharge pipe (see Fig. 1).
Table 1. Four samples collected from gold mine tailings.

\begin{tabular}{lll}
\hline Samples & Mass $(\mathrm{kg})$ \\
\hline Decommissioned site (mixed) & 0.530 \\
& Dried tailings & 0.530 \\
\multirow{3}{*}{ Commissioned site } & $200 \mathrm{~m}$ away & 0.530 \\
& Decent & 0.530 \\
& Source & 0.530 \\
\hline
\end{tabular}

Various spectra were generated from the spectrometric analysis of the samples and were used to identify different radionuclides in each sample. Potassium $\left({ }^{40} \mathrm{~K}\right.$ and the radionuclides in Uranium ${ }^{238} \mathrm{U}$ and thorium ${ }^{232} \mathrm{Th}$ series were identified from the spectra and their activities calculated. The activity concentration levels of ${ }^{238} \mathrm{U}$, ${ }^{232} \mathrm{Th}$ and ${ }^{40} \mathrm{~K}$ in the soil tailing samples from Vatukoula Gold mines were obtained using the equation (1). Their activity concentration levels were tabulated and the results are presented in Table 2. Soil mine tailing samples from Vatukoula gold mine had the highest total activity concentrations at the source of the commissioned site which is currently in use but this is less than the total activity concentration of the worldwide average according to the [1] report.

The average concentration of ${ }^{238} \mathrm{U},{ }^{232} \mathrm{Th}$ and ${ }^{40} \mathrm{~K}$ of both the sites compared with the World averages adapted from the United Nations Scientific Committee on the Effects of Atomic Radiation were calculated and results are summarized in Table 3.

Potassium ${ }^{40} \mathrm{~K}$ had the highest activity concentration, followed by Thorium $\left({ }^{232} \mathrm{Th}\right)$ than Uranium $\left({ }^{238} \mathrm{U}\right)$ which was considered a series of Radium $\left({ }^{226} \mathrm{Ra}\right)$. This could be due to the natural abundance of ${ }^{40} \mathrm{~K},{ }^{232} \mathrm{Th}$ and ${ }^{238} \mathrm{U} .{ }^{40} \mathrm{~K}$ is found in most terrestrial materials with an abundance of $0.012 \%$ while ${ }^{232} \mathrm{Th}$ is about three times more abundant than ${ }^{238} \mathrm{U}$ in the earth's crust [1]. Therefore, the activity levels of ${ }^{232} \mathrm{Th}$ are expected to be higher than those of ${ }^{238} \mathrm{U}$.

This may be due to rich magma basaltic origin, monzonite derivatives and other accessory minerals. The rocks of the ancient Vatukoula Volcano originated as potassium-rich magma with a series of transformation reach to parent magma to shoshonite, banakite and monzonite derivatives [17] covering the most of the region.

Igneous rocks of granite composition contain most of the terrestrial radionuclides. The total activity concentrations of ${ }^{238} \mathrm{U}$, and ${ }^{40} \mathrm{~K}$ of the two sites are lower than the world averages except for ${ }^{232} \mathrm{Th}$ in the commissioned site which is three times higher than the world average due to its monazite derivatives.

The preliminary results of this study reveal that the natural radionuclides of ${ }^{238} \mathrm{U}$ and ${ }^{40} \mathrm{~K}$ were found present in low levels in all the samples studied and varies with ${ }^{232} \mathrm{Th}$ due to its volcanic origins and the differences in geological structure. The literature has repeatedly indicated that ${ }^{238} \mathrm{U},{ }^{232} \mathrm{Th}$ and ${ }^{40} \mathrm{~K}$ concentrations in soil vary according to 


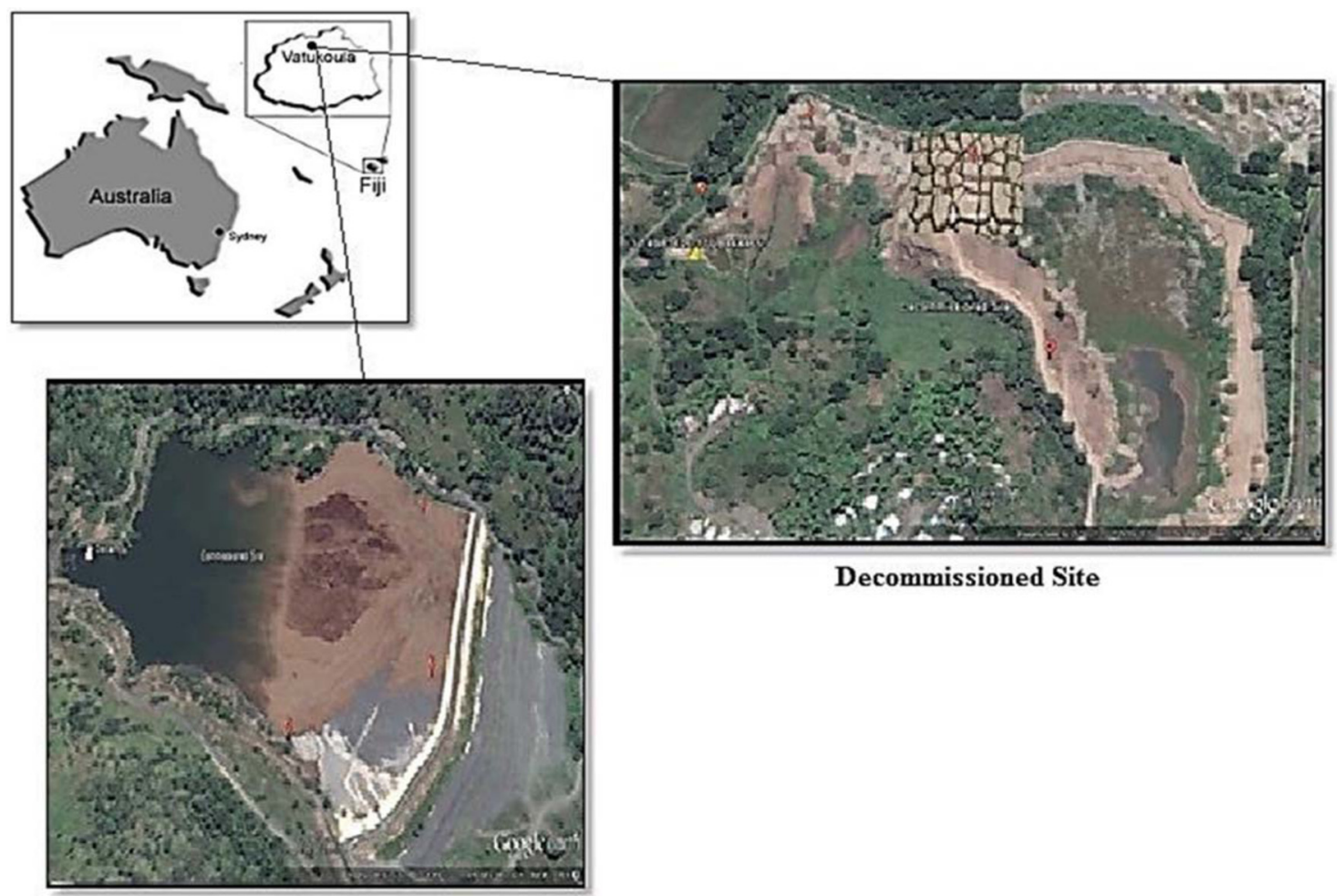

Commissioned Site

Fig. 1. Regional map showing location of Vatukoula and the sample sites.

Table 2. Activity concentrations of ${ }^{238} \mathrm{U},{ }^{232} \mathrm{Th}$ and ${ }^{40} \mathrm{~K}$ in mine tailing samples with the world average values adapted from the (UNSCEAR 2000).

\begin{tabular}{|c|c|c|c|c|c|}
\hline \multirow{2}{*}{\multicolumn{2}{|c|}{ Site }} & \multicolumn{3}{|c|}{ Activity concentration $\left(\mathrm{Bq} \mathrm{kg}^{-1}\right)$} & \multirow{2}{*}{$\begin{array}{l}\text { Total Activity } \\
\text { Concentrations }\left(\mathrm{Bq} \mathrm{kg}^{-1}\right)\end{array}$} \\
\hline & & ${ }^{238} \mathrm{U}$ & ${ }^{232} \mathrm{Th}$ & ${ }^{40} \mathrm{~K}$ & \\
\hline \multicolumn{2}{|c|}{ World average (UNSCEAR) } & 33.0 & 45.00 & 420.00 & 498.00 \\
\hline \multicolumn{2}{|c|}{ Decommissioned (Mixed) } & 30.70 & 0 & 175.73 & 206.43 \\
\hline \multirow{4}{*}{ Commissioned site } & 200 m Away & 47.92 & 0 & 69.09 & 117.01 \\
\hline & Dried Tailing & 0 & 0 & 98.30 & 98.30 \\
\hline & Decant & 22.91 & 0 & 46.32 & 69.23 \\
\hline & Source & 7.138 & 129.06 & 133.72 & 269.91 \\
\hline
\end{tabular}

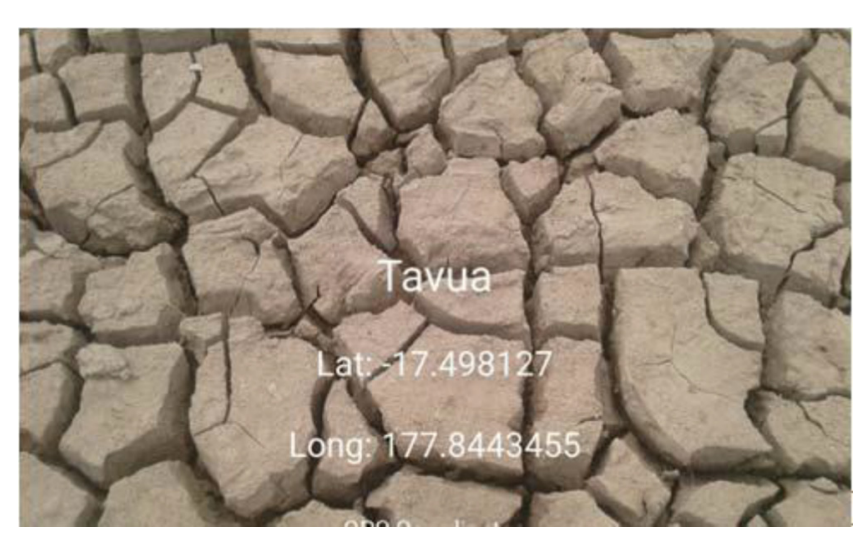

Fig. 2. Gold mining - dried tailings. the geological formation, physico-geological characteristics of soil types, topographical differences, geomorphology and meteorological conditions of the region.

Other natural radionuclides appeared at trace levels in some samples studied and were ignored. The presence of ${ }^{238} \mathrm{U},{ }^{232} \mathrm{Th}$ and ${ }^{40} \mathrm{~K}$ in the soil mine tailings was expected since these radionuclides occur in nature in all soil types but with varying elemental concentrations.

This study revealed that the total concentrations of ${ }^{238} \mathrm{U},{ }^{232} \mathrm{Th}$ and ${ }^{40} \mathrm{~K}$ collected for the soil mine tailings from Vatukoula were lower than that of the world average values quoted in [1] report. Anthropogenic or manmade radionuclides, such as Cesium $\left({ }^{137} \mathrm{Cs}\right)$ were not detected in the present study that indicates that Vatukoula is free of anthropogenic radionuclides, which originates 
Table 3. Average activity concentration of the decommissioned and the commissioned site compared with the world averages (UNSCEAR 2000).

\begin{tabular}{lllll}
\hline Site & Reference & ${ }^{238} \mathrm{U}\left(\mathrm{Bq} \mathrm{kg}^{-1}\right)$ & ${ }^{232} \mathrm{Th}\left(\mathrm{Bq} \mathrm{kg}^{-1}\right)$ & $\left.{ }^{40} \mathrm{~K}_{(\mathrm{Bq} \mathrm{kg}}{ }^{-1}\right)$ \\
\hline Decommissioned & & 30.7 & 0 & 175.73 \\
Commissioned & & 19.49 & 129.06 & 86.86 \\
World & UNSCEAR2000 & 33 & 45 & 420 \\
\hline
\end{tabular}

from nuclear weapons testing and unforeseen nuclear accidents.

\section{Conclusions}

The natural radioactivity levels of mine tailings from Vatukoula Gold Mine Fiji Limited (VGML) were determined. The activity concentration levels of ${ }^{23} \mathrm{U},{ }^{232} \mathrm{Th}$ and ${ }^{40} \mathrm{~K}$ in soil mine tailing samples have been studied using NaI (Tl) gamma-ray spectrometry. The results obtained showed that the distribution of natural radionuclides in the soil samples was not uniform and artificial radionuclide was not detected in any sample measured.

The average activity concentrations in all the sites were lower than the world average according to the [1] report. Therefore, mining activities Vatukoula poses no significant radionuclide hazard to the miners and the general public.

The research focuses on three elements only, however, more information could be gathered if other trace elements or a completed gamma profile can be conducted for the collapsed caldera of an extinct volcano, near the edge of the Nakauvadra mountain range in Vatukoula.

While the NaI(TI) Scintillator is reliable for radioactive measurements, the methodology determines the activity concentration of radionuclides only, more information could be gathered if the diametric analysis like dose rate and hazard indices is conducted.

\section{Recommendation}

The present research work could also be extended to include the tailings radiation hazard assessment. It is recommended that the present preliminary study be extended to investigate the soil samples from the gold mine tailings in Vatukoula, Fiji, including its surrounding areas within the radius of about 5 kilometers and the counting time be increase to 24 hours ( 86,400 seconds) to get results that are more meaningful on NORMs at gold mine areas. It is strongly recommended that regular monitoring of soil samples of gold mine tailings and its surrounding areas be initiated.

The authors acknowledge the technical support given by the VGML team. The technical help from Mr. Ashmit Kumar of the Department of Physics, Fiji National University is appreciated.

\section{References}

1. United Nations Scientific Committee on the Effects of Atomic Radiation UNSCEAR Report to the General Assembly with Scientific Annexes United Nations New York 2000; 2000

2. Impact assessment of naturally occurring radioactive materials on the public from gold mining and processing at Newmont Golden Ridge Limited, Akyem, Ghana Radiat. Protect. Environ. 39, 155-164 (2016)

3. M.A. Uosif, S.A. Issa, El-L.M. Abd Salam, Measurement of natural radioactivity in granites and its quartz-bearing gold at El-Fawakhir Area (Central Eastern Desert), Egypt, J. Radiat. Res. Appl. Sci. 8, 393-398 (2015)

4. C. Kamunda, M. Mathuthu, M. Madhuku, An assessment of radiological hazards from gold mine tailings in the province of Gauteng in South Africa, Int. J. Environ. Res. Public Health 13, 138 (2016)

5. D.S. Hammond, V. Gond, B. de Thoisy, P.-M. Forget, B.P.E. DeDijn. Causes and consequences of a tropical forest gold rush in the Guiana Shield, South America, Ambio 36, 661670 (2007)

6. A.I. Abd El-Mageed, A. El-Kamel, S. Harb, A.M.M. Youssef, I.I. Saleh, Assessment of natural and anthropodenic radioactivity levels in rocks and soils in the enviorns of Jordan Town in Yemen, in Tenth Radiation Physics \&6 protection Conference, 27-30 November 2010, Nasr City Cairo, Egypt

7. A.K. Ademola, A.K. Bello, A.C. Adejumobi, Determination of natural radioactivity and hazard in soil samples in and around gold mining area in Itagunmodi, South-Western, Nigeria, J. Radiat. Res. Appl. Sci. 7, 249-255 (2014)

8. M. Ali, A.A. Qureshi, A. Waheed, M.A. Baloch, H. Qayyum, M. Tufail, H.A. Khan, Assessment of radiological hazard of norm in Margella Hills Limestone, Pakistan, Environ. Monit. Assess. 184, 4623-4634 (2012)

9. R.M. Amin, Gamma radiation measurements of naturally occuring radioactive samples from commercial Egyptian granites, Environ. Earth Sci. 67, 771-775 (2012)

10. R.M. Amin, Radioactivity levels in some sediments and water samples from qarun lake by low-level gamma spectroscopy, Int. J. Sci. Res. 4, 619-625 (2015)

11. A.V. De Groot, E.R. van der Graaf, R.J. de Meijer, M. Maucec, Sensitivity of in-situ $\gamma$-ray spectra to soil density and water content, Nucl. Instr. Methods Phys. Res. A 600, 519523 (2009)

12. D.G. Blanchard, N.E. Louis, N.N. Emmanuel II, T.S. Saïdou, Y. Flore, B. Daniel, N.M. Godfroy, NORM measurements and radiological hazard assessment in the gold mining Areasa of Eastern Cameroon, Radiat. Environ. Med. 6, 22-28 (2017) 
13. S. Garimella, U. Prasad, Distribution of 40K, $232 \mathrm{Th}$ and $238 \mathrm{U}$ in soils of southern and western Coasts of Viti Levu, Fiji, S. Pac. J. Nat. Sci. 20, 9-14 (2002)

14. E.R. Silver Turyahabwa, E. Jurua, R. Oriada, A. Mugaiga, D.D. Ben Enjiku, Determination of natural radioactivity levels due to mine tailings from selected mines in Southwestern Uganda, J. Environ. Earth Sci. 6 (2016)

15. M.R. Usikalu, O.C. Anoka, F.A. Balogun, Radioactivity measurements of the Jos Tin mine tailing in Northern Nigeria, scholars research library, Arch. Phys. Res. 2, 80-86 (2011)

16. Sinclair Knight Merz Pty Ltd. Environmental Audit of Emperor Gold Mines 1994; https://www.sprep.org/att/irc/ ecopies/countries/fiji/135.pdf
17. Mineral Resources Department (MRD) Government of Fiji 1990; http://www.mrd.gov.fj/images/Geological_Survey/ Fiji_Geology__Minerals.pdf

18. P.J. Boon, P.J. Raven, River Conservation and Management (Willey-Blackwell, 2012)

19. International Atomic Energy Agency (IAEA) Soil Sampling for Environmental Contamination IAEA - TECDOC 2004; 1415

20. A.Q. Malik, A. Kumar, Monitoring of Environmental Radioactivity in Foodstuff in Fiji. International Journal of Science and Research, 8, 1781-1785, 2019.

21. M. Tufail, N. Akhtar, J. Sabia, T. Hamid, Natural Radioactivity Hazards of Building Bricks Fabricated form saline Soil of two Districits of Pakistan. Journal of Radiological Protection, 27, 481-492, 2007.

Cite this article as: Adimaitoga T.William Rabuku, Abdul Q. Malik, Natural radioactivity measurement of gold mine tailings in Vatukoula, Fiji Islands, Renew. Energy Environ. Sustain. 5, 10 (2020) 